\title{
Dopamine in models of alcoholic acute pancreatitis
}

\author{
N D Karanjia, A L Widdison, F J Lutrin, H A Reber
}

\section{Abstract}

Acute oedematous pancreatitis and acute haemorrhagic pancreatitis were studied using the low pressure duct perfusion models of alcoholic pancreatitis in cats. After creating either form over 24 hours, each pancreas was histologically graded and assigned an inflammatory score (0-16; absent-severe). Urinary trypsinogen activation peptide concentrations were also used as a measure of severity. Using the model of acute haemorrhagic pancreatitis, it was previously shown that low dose dopamine $(5 \mu \mathrm{g} / \mathrm{kg} . \mathrm{m})$ reduced the inflammatory score at 24 hours and that this effect was mediated by a reduction in pancreatic microvascular permeability acting via dopaminergic and beta adrenergic receptors. Further studies were conducted and are reported here. In experiment 1 different doses of dopamine in established alcoholic acute haemorrhagic pancreatitis were studied. In group 1 control cats (no dopamine), the inflammatory score was 10.5 (interquartile range (IQR)4). In groups 2 , 3 , and 4, haemorrhagic pancreatitis was induced. Twelve hours later dopamine was infused for six hours, in the doses of $2 \mu \mathrm{g} /$ kg.min, $5 \mu \mathrm{g} / \mathrm{kg}$.min, and $50 \mu \mathrm{g} / \mathrm{kg}$.min respectively. The inflammatory score in group 2 was 7 (IQR 0.5, p $<0.05 v$ group 1), in group 3 it was 7 (IQR 2, $p<0.05 v$ group 1 ), and in group 4 it was 7 (IQR 4, p < 0.05 $v$ group 1). This was matched by significantly lower levels of urinary tripsinogen activation peptide at 24 hours. In experiment 2 (group 5) we tried to reduce microvascular permeability further by combining dopamine with antihistamines, but there was no improvement in the inflammatory score. As oedematous pancreatitis is the commoner and milder form of acute pancreatitis in clinical practice, in experiment 3 we looked at the effect of dopamine in this model. In group 6 control cats (no treatment), the inflammatory score was 7 (IQR 3, p < $0.05 v$ group 1). In group 7 cats given dopamine $(5 \mu \mathrm{g} / \mathrm{kg} \cdot \mathrm{min}$ for six hours) from 12 hours after the onset of acute oedematous pancreatitis, the inflammatory score was reduced to 4 (IQR 2, p $<0.05 v$ group 6). This was matched by a significant reduction in the 24 hour urinary tripsin activation peptide concentration.

(Gut 1994; 35: 547-551)

In the low pressure duct perfusion model of acute pancreatitis in cats, ${ }^{1-4}$ intragastric alcohol renders the main pancreatic duct permeable to pancreatic enzymes. Perfusion of a permeable duct with activated pancreatic juice causes acute oedematous pancreatitis (AOP). If 16-16 dimethyl prostaglandin $E_{2}$ is also infused intravenously, AOP becomes acute haemorrhagic pancreatitis (AHP). We previously showed that dopamine reduced the severity of AHP when administered within 12 hours of the induction of this disorder. ${ }^{5}$ This effect was due to a reduction in microvascular permeability mediated by the stimulation of either dopaminergic or betaadrenergic receptors. ${ }^{67}$

Here, in a further progression of these experiments, we analysed three more issues. In experiment 1 we examined the effect of varying the dose of dopamine in the original model of alcoholic AHP. In experiment 2 we investigated whether the addition of the $\mathrm{H}_{1} / \mathrm{H}_{2}$ blockers, diphenhydramine and cimetidine, might have a synergistic effect if combined with dopamine as these latter agents would be expected to reduce microvascular permeability by an action through different receptors. In experiment 3 we investigated the effect of dopamine in the model of alcoholic AOP because in humans alcohol often leads to the milder oedematous form of acute pancreatitis.

\section{Methods}

THE MODELS

The models have been described in detail previously ${ }^{1-4}$ and are considered briefly here.

\section{Alcoholic AOP}

Fasted cats were anaesthetised and after drawing samples for estimating basal serum lipase and urinary tripsinogen activation peptide (TAP), a laparotomy was performed. The body of the stomach was cannulated with the tip of the cannula sited in the antrum. The main pancreatic duct was cannulated in the tail of the pancreas with plastic tubing that had previously been filled with a physiological salt solution (standard per-

TABLE I The inflammatory scoring system for acute pancreatitis

Architecture
0 - Normal.
1 - Periductal parenchymal destruction.
2 - Focal parenchymal necrosis away from ducts.
3 - Diffuse parenchymal loss in less than $50 \%$ of lobules.
4 - Diffuse parenchymal loss in greater than $50 \%$ of lobules.
Inflammatory cell infiltrate
0 - None.
1 - In ducts/around ductal margins/scattered polymorphs.
2 - In the parenchyma in less than $50 \%$ of lobules.
3 - In the parenchyma in more than $50 \%$ of lobules.
4 - Massive collections/abscesses.
Haemorrhage
0 - None.
1 - Blood in the parenchyma in less than $25 \%$ of lobules.
2 - Blood in the parenchyma in $25 \%-50 \%$ of lobules.
3 - Blood in the parenchyma in $50 \%-75 \%$ of lobules.
4 - Blood in the lobules.
Oedema
0 - Normal.
1 - Focally increased between lobules.
2 - Diffusely increased between lobules.
3 - Widely separated lobules/tense acini.
4 - Gross lobular separation/cobblestoning.

Department of Surgery

London

N D Karanjia

A $\mathrm{L}$ Widdison

Correspondence to:

Mr N D Karanjia, Frimley

Park Hospital, Portsmouth

Road, Frimley GU16 5UJ

Accepted for publication

26 July 1993
Department of Surgery Sepulveda, and UCLA Los Angeles, California F J Lutrin 
fusate) and connected to a constant rate perfusion pump. Twenty $\mathrm{ml}$ of $40 \%$ ethanol were slowly instilled through the gastric cannula over 10 minutes, and the main pancreatic duct was perfused for one hour with standard perfusate at $0.5 \mathrm{ml} / \mathrm{h}$. At this rate of perfusion, the pressure within the duct never exceeded $10 \mathrm{~mm} \mathrm{Hg}$ (the maximum secretory pressure of the cat pancreas is less than $20 \mathrm{~mm} \mathrm{Hg}^{8}$ ). Then the main pancreatic duct was perfused with activated pancreatic juice for one hour. This juice had previously been collected from donor cats, standardised, and activated just before administration. After two hours when these perfusions were over, the cannula was cut, then ligated, and the abdomen was closed. Anaesthesia was maintained for 24 hours when serum lipase and urinary tripsinogen activation peptide were remeasured. The pancreas was then examined, sections taken for histological analysis, and the cat was killed.

\section{Alcoholic AHP}

Alcoholic AHP was induced as follows. Mongrel cats were prepared as above, but in addition, but in addition, at the main pancreatic duct perfusion was started with standard perfusate, an intravenous infusion of 16-16 dimethyl prostaglandin $\mathrm{E}_{2}\left(\mathrm{PGE}_{2}\right)$ in saline $(2 \mu \mathrm{g} / \mathrm{kg} \cdot \mathrm{hr} ; 2 \mathrm{ml} / \mathrm{h}$ for two hours) was also started to convert AOP to AHP. This infusion was complete at the end of the two main pancreatic duct perfusions. Anaesthesia was maintained for 24 hours, after which serum lipase and urinary trypsinogen activation peptide were measured, the pancreas was examined, and the cat killed.

\section{ASSESSMENT OF PANCREATIC DAMAGE}

The effects of treatment with dopamine were assessed in two ways. Firstly, pancreatic inflammation was graded by strict histological criteria and these were then used to make comparisons. ${ }^{24}$ Secondly, urinary trypsinogen activation peptide concentrations were measured as this has been shown to be an indicator of the severity of acute pancreatitis. $^{910}$

\section{Inflammatory scoring system}

An inflammatory score was assigned to each cat, after examining histological sections in a blinded manner. The inflammatory score (0-16; absentsevere) was the sum of subscores $(0-4)$ based on four criteria: architectural damage (parenchymal necrosis), polymorphonuclear cell infiltrate, intraparenchymal haemorrhage and oedema (Table I).

\section{Assays}

Serum lipase was assayed using a standard turbidimetric method. ${ }^{11}$ Urine for tripsinogen activation peptide was collected by aspirating $2 \mathrm{ml}$ from the bladder of each cat. Twenty $\mu \mathrm{l}$ of $0.5 \mathrm{M}$ ethylene-diamine-tetra-acetic acid (final concentration $5 \mathrm{mM}$ EDTA) were added to each sample to prevent degradation of the tripsinogen activation peptide analyte by aminopeptidases (inhibited by chelating active site zinc). All samples were frozen to minus $70^{\circ} \mathrm{C}$ until analysed using an enzyme linked immunosorbent assay (ELISA), the non-isotopic equivalent of the original radioimmunoassay (RIA). ${ }^{912}$

EXPERIMENT 1: THE EFFECT OF DIFFERENT DOSES OF DOPAMINE ON THE TREATMENT OF ESTABLISHED ALCOHOLIC AHP

Randomised groups of mongrel cats with AHP were treated with either saline or different doses of dopamine from 12 hours after the main pancreatic duct perfusions used to induce AHP had ended. All infusions were given at $2 \mathrm{ml} / \mathrm{h}$ for six hours.

Group 1 (AHP controls): these cats received normal saline intravenously.

Group 2: these cats received an intravenous infusion of $2 \mu \mathrm{g} / \mathrm{kg}$. min of dopamine.

Group 3: this group received an intravenous infusion of $5 \mu \mathrm{g} / \mathrm{kg}$.min of dopamine.

Group 4: these cats received an intravenous infusion of $50 \mu \mathrm{g} / \mathrm{kg} \cdot \mathrm{min}$ of dopamine.

\section{EXPERIMENT 2: THE EFFECT OF COMBINED}

DOPAMINE AND HISTAMINE RECEPTOR

ANTAGONISTS IN THE TREATMENT OF

ESTABLISHED AHP

Group 5 cats received an intravenous infusion of $5 \mu \mathrm{g} / \mathrm{kg}$.min of dopamine combined with the $\mathrm{H}_{1}$ receptor blocker diphenhydramine $(2 \mathrm{mg} / \mathrm{kg})$ and the $\mathrm{H}_{2}$ receptor blocker cimetidine $(10 \mathrm{mg} /$ $\mathrm{kg}$ ), starting 12 hours after the end of the main pancreatic duct perfusions used to induce AHP. This infusion was also given at $2 \mathrm{ml} / \mathrm{h}$ for six hours.

EXPERIMENT 3: THE EFFECT OF DOPAMINE ON ESTABLISHED ALCOHOLIC AOP

Mongrel cats that were to develop alcoholic AOP in this study, were prepared as described above and were randomised into 2 groups: controls and those receiving dopamine for established disease. The infusions were started 12 hours after the main pancreatic duct perfusions used to induce AHP had finished and were given at the rate of 2 $\mathrm{ml} / \mathrm{h}$ for six hours.

Group 6 (AOP controls): these cats received normal saline intravenously.

Group 7: these cats received an intravenous infusion of $5 \mu \mathrm{g} / \mathrm{kg}$. min of dopamine.

\section{STATISTICAL METHODS}

The data were expressed as median values (Interquartile range; IQR). Ordinal data were compared by the Mann-Whitney U test when looking at differences between groups and the Wilcoxon test for pairs when looking at changes within groups. Nominal data were analysed using Fisher's exact test. Statistical significance was assumed when $\mathrm{p}<0.05$.

\section{Results}

EXPERIMENT 1

The results are shown in Table II. In this 
TABLE II Experiments 1 and 2, alcohol haemorrhagic pancreatitis. The effect of different doses of dopamine and the effect of adding antihistamines

\begin{tabular}{|c|c|c|c|c|c|}
\hline Protocol 1 & $\begin{array}{l}\text { Group } 1 \\
\text { Saline } \\
\text { (controls) } \\
n=8\end{array}$ & $\begin{array}{l}\text { Group } 2 \\
\text { Dopamine } \\
(2 \mu g / \text { kg.min }) \\
n=6\end{array}$ & $\begin{array}{l}\text { Group } 3 \\
\text { Dopamine } \\
(5 \mu g / k g . \min ) \\
n=8\end{array}$ & $\begin{array}{l}\text { Group } 4 \\
\text { Dopamine } \\
(50 \mu g / \text { kg.min }) \\
n=6\end{array}$ & $\begin{array}{l}\text { Group } 5 \\
\text { Dopamine } 5 \mu \mathrm{g}+ \\
\text { antihistamine } \\
n=6\end{array}$ \\
\hline $\begin{array}{l}\text { Inflammatory score: } \\
\text { Architectural damage } \\
\text { PMN infiltrate } \\
\text { Haemorrhage } \\
\text { Oedema }\end{array}$ & $\begin{array}{l}10 \cdot 5(4) \\
3(1) \\
3(0 \cdot 5) \\
2 \cdot 5(2) \\
2(1)\end{array}$ & $\begin{array}{l}7(0 \cdot 5)^{\star} \\
2 \\
1 \cdot 5(1)^{\star} \\
2\end{array}$ & $\begin{array}{l}7(2 \cdot 5)^{\star} \\
2(0 \cdot 5)^{\star} \\
2(0 \cdot 5)^{\star} \\
2(1) \\
1^{\star}\end{array}$ & $\begin{array}{l}7(4)^{\star} \\
2(1)^{\star} \\
1 \cdot 5(1)^{\star} \\
2(1)^{\star} \\
1 \cdot 5(1)\end{array}$ & $\begin{array}{l}7(1 \cdot 5)^{\star} \\
1 \cdot 5(1)^{\star} \\
2(1)^{\star} \\
2(2) \\
1 \cdot 5(1)^{\star}\end{array}$ \\
\hline $\begin{array}{l}\text { Serum lipase (U/I): } \\
\text { Basal } \\
\text { At } 24 \text { hours } \\
\text { Urine TAP nmol/l: }\end{array}$ & $\begin{array}{c}25(14) \\
145(75) \ddagger\end{array}$ & $\begin{array}{l}25(20) \\
60(69)^{\star} \ddagger\end{array}$ & $\begin{array}{l}21(9) \\
22(19)^{\star}\end{array}$ & $\begin{array}{l}20(18) \\
22(25)^{\star}\end{array}$ & $\begin{array}{l}12(12) \\
50(78) \dagger\end{array}$ \\
\hline $\begin{array}{l}\text { Basal } \\
\text { At } 24 \text { hours }\end{array}$ & $\begin{array}{c}5(9) \\
144(220) \ddagger\end{array}$ & $\begin{array}{l}11(23) \\
110(20)^{\star} \ddagger\end{array}$ & $\begin{array}{l}12(12) \\
108(89) \dagger \ddagger\end{array}$ & - & $\begin{array}{l}- \\
-\end{array}$ \\
\hline
\end{tabular}

$\star=p<0.05$, versus group 1 controls, Mann-Whitney $U$ test. In addition $\dagger=p<0.07, \ddagger=p<0.05$, versus basal values, Wilcoxon test for

$\mathrm{PMN}=$ polymorphonuclear cells; $\mathrm{TAP}=$ trypsinogen activating peptide

experiment, group 1 control cats all developed AHP with a high inflammatory score of 10.5 (IQR 4) and high subscores for haemorrhage 2.5 (IQR 2) and polymorphonuclear cell infiltration $3(0 \cdot 5)$. This was matched by high serum lipase and urinary tripsinogen activating peptide values at 24 hours.

In groups 2, 3, and 4, in which established AHP was treated with different doses of dopamine, the inflammatory score was 7 in all three groups, and this was significantly better than that seen in group 1. A significant reduction in the subscore for pancreatic polymorphonuclear cell infiltration was seen in all three treated groups compared with the control group 1 . Serum lipase and urinary tripsinogen activating peptide values at 24 hours were also lower than in group 1.

There was no significant difference in the results between groups 2,3 , and 4 with regard to reduction in the inflammatory score compared with group 1 controls.

\section{EXPERIMENT2}

In group 5 cats in which established AHP was treated with $5 \mu \mathrm{g} / \mathrm{kg}$.min dopamine combined with $\mathrm{H}_{1}$ and $\mathrm{H}_{2}$ receptor blockers, while the inflammatory score was significantly better than that in the control group 1, it was the same as that seen in groups 2,3 , and 4 . The subscores for architectural damage, polymorphonuclear cell infiltrate, and oedema were significantly better than in group 1 controls. The serum lipase

TABLE III Experiment 3, alcoholic oedematous pancreatitis. The effect of dopamine $5 \mu \mathrm{g} / \mathrm{kg}$. min in a model of alcoholic oedematous pancreatitis

\begin{tabular}{|c|c|c|}
\hline Protocol 2 & $\begin{array}{l}\text { Group } 6 \\
\text { Saline controls } \\
n=7\end{array}$ & $\begin{array}{l}\text { Group } 7 \\
\text { Dopamine } \\
(5 \mu g / \text { kg. min }) \\
n=7\end{array}$ \\
\hline $\begin{array}{l}\text { Inflammatory score: } \\
\text { Architectural damage } \\
\text { PMN infiltrate } \\
\text { Haemorrhage } \\
\text { Oedema }\end{array}$ & $\begin{array}{l}7(3) \\
2 \\
2(1) \\
2(2) \\
2\end{array}$ & $\begin{array}{l}4(2)^{\star} \\
1(1 \cdot 5) \\
1(1) \\
1 \\
1^{\star}\end{array}$ \\
\hline $\begin{array}{l}\text { Serum lipase (U/I): } \\
\text { Basal } \\
\text { At } 24 \text { hours }\end{array}$ & $\begin{array}{l}22(10) \\
41(62)\end{array}$ & $\begin{array}{l}19(13) \\
41(30)\end{array}$ \\
\hline $\begin{array}{l}\text { Urinary TAP nmol/l: } \\
\text { Basal } \\
\text { At } 24 \text { hours }\end{array}$ & $\begin{array}{c}17(30) \\
117(78) \dagger\end{array}$ & $\begin{array}{l}11(13) \\
59(17)^{\star} \dagger\end{array}$ \\
\hline
\end{tabular}

${ }^{\star}=\mathrm{p}<\mathbf{0 . 0 5}$ versus group 1 controls, Mann-Whitney $U$ test. $t=p<0.05$ versus basal values, Wilcoxon test for pairs. $\mathrm{PMN}=$ polymorphonuclear cells; TAP = tripsinogen activating peptide. activities at 24 hours were low and significantly lower than in group 1 controls.

\section{EXPERIMENT 3}

Table III shows that the inflammatory score was 7 (IQR 3) in group 6 controls. This was significantly better than that seen in group 1 controls who developed AHP. Group 7 cats, who received delayed treatment with dopamine, had a significantly better inflammatory score 4 (IQR 2), largely due to a significant reduction in the subscores for architectural damage and oedema.

Serum lipase activities at 24 hours were not significantly increased from basal values in both groups 6 and 7 . Although 24 hour urinary tripsinogen activating peptide values were significantly raised in both groups 6 and 7, group 7 cats had significantly lower values than group 6 control cats.

THE CARDIOVASCULAR EFFECTS OF DOPAMINE

The blood pressure was monitored for the duration of all procedures and remained stable in most animals until the onset of dopamine. Thereafter the pressure became labile and the pulse pressure widened, although the mean arterial pressure remained constant.

\section{Discussion}

Most patients who develop acute pancreatitis have the milder oedematous form and recover without sequelae. Between 5\% and $20 \%$, however, develop haemorrhagic and necrotising forms of acute pancreatitis which are more severe and have a high mortality. ${ }^{1314}$ Despite extensive research, no agents have been found that influence the severity of pancreatic inflammation and treatment remains supportive unless complications supervene. Dopamine is a vasoactive drug that is known to improve renal perfusion and has a positive inotropic and chronotropic effect. ${ }^{15} 16$ For these reasons it is frequently used to support critically ill patients, including those with fulminating acute pancreatitis.

Extrapolation from animal models to the human situation is fraught with difficulty. In the low pressure duct perfusion model in cats, intragastric alcohol, intraductal bile salts, and systemic hypercalcaemia all lead to an increase in 
ductal permeability. While studies are still awaited to see whether the ingestion of ethanol in humans also leads to an increase in pancreatic ductal permeability, the model used in these experiments is interesting, particularly as ductal perfusion with activated juice leads to acute pancreatitis only in cats with permeable ducts. The models used in these studies are complex but they may have some bearing on the human disease.

Recent experiments in different animal models have shown that when a dopamine infusion is started within 12 hours of the onset of acute pancreatitis it reduces the severity of the pancreatic inflammation. ${ }^{51718}$ In our experiments dopamine was started 12 hours after the induction of acute pancreatitis so as to reproduce the clinical situation in which there is an inevitable delay in initiation of treatment for most patients. Experiment 1 has shown that this anti-inflammatory effect of dopamine is sustained at both low ( 2 and $5 \mu \mathrm{g} / \mathrm{kg} . \mathrm{min})$ and high doses (50 $\mu \mathrm{g} / \mathrm{kg} \cdot \mathrm{min})$.

Dopamine stimulates three different receptor systems. ${ }^{15}{ }^{16}$ In the dose range $1-4 \mu \mathrm{g} / \mathrm{kg}$. min, the effect is predominantly on dopaminergic receptors, leading to improved renal and mesenteric blood flow with minimal cardiac effect. In the range 4-10 $\mu \mathrm{g} / \mathrm{kg} . \mathrm{min}$, beta adrenergic receptors are increasingly stimulated leading to a positive inotropic effect on the myocardium. Above this range alpha adrenergic receptors are additionally activated. ${ }^{\text {is }}$ We have previously shown that the anti-inflammatory effect of dopamine, when infused at $5 \mu \mathrm{g} / \mathrm{kg}$.min is completely blocked by dopaminergic and beta-adrenergic receptor antagonists. ${ }^{6}$ In experiment 1 , identical antiinflammatory effects were seen for the 5 and 50 $\mu \mathrm{g} / \mathrm{kg} \cdot \mathrm{min}$ doses suggesting that there is no alpha-adrenergic receptor contribution to the effects seen in this study. This supports earlier observations from experiments on receptor blockade. $^{6}$

Inflammation of the pancreas is accompanied by the release of vasoactive agents such as histamine, bradykinin, prostaglandins, etc, ${ }^{1920}$ both into ascitic fluid and into the systemic circulation. These agents lead to endothelial cell contraction with the formation of gaps in the vascular wall. ${ }^{2122}$ The concomitant increase in microvascular permeability may be responsible for the genesis of pancreatic parenchymal haemorrhage. We have previously shown that the anti-inflammatory effect of dopamine is the result of a reduction in pancreatic microvascular permeability ${ }^{67}$ mediated through the stimulation of dopaminergic and beta adrenergic receptors. ${ }^{6}$ In experiment 2 (group 5) we tried to reduce the local inflammatory response further by inhibiting histaminergic receptors too. We have shown no significant improvement in either the inflammatory score or its subscores in comparison with groups 2, 3, and 4, suggesting that the maximal reversal of microvascular permeability has already been achieved with dopamine alone.

A criticism of the results from the studies in experiment 1 might be that dopamine merely reversed the effect of the exogenously administered 16-16 $\mathrm{PGE}_{2}$ used to create AHP. It may be argued, however, that the prostaglandin was administered 12 hours before dopamine was given and that the temporal relationship of these agents would therefore be against such an explanation. Furthermore, the results from experiment 3 showed that low dose dopamine was extremely effective in reducing the degree of inflammation in established alcohol related AOP where exogenous $\mathrm{PGE}_{2}$ was not administered.

We performed experiment 3 to look at the effect of dopamine in a model of oedematous pancreatitis, because in humans alcohol often leads to mild oedematous pancreatitis which is self-limiting. The effect of dopamine in downmodulating the degree of inflammation in this model could mean an improved speed of resolution in humans. Thus, a case could be made for treating all forms of alcohol pancreatitis with dopamine.

In summary, our experiments in models of alcohol related AOP and AHP have shown that dopamine is effective in reducing the degree of inflammation in established pancreatitis. This is largely independent of dose and the addition of inflammation in established pancreatitis. This is largely independent of dose and the addition of histamine receptor blockers has no potentiating effect. We suggest that either dopamine or its analogue dopexamine should be tried clinically in all patients presenting with acute pancreatitis; a renal dose may be optimal.

The authors are grateful to Professor J Hermon-Taylor, of the Department of Surgery, St George's Hospital, London for help with the TAP assay and for editing the manuscript.

1 Wedgewood KR, Adler G, Kern H, Reber HA. Effects of oral agents on pancreatic duct permeability: a model of acute agents on pancreatic duct permeability: a model
alcoholic pancreatitis. Dig Dis $S c i$ 1986; 31: 1081-8.

2 Harvey MH, Cates M, Reber HA. Possible mechanisms of acute pancreatitis induced by ethanol. Am $\mathcal{F}$ Surg 1988; 155: 49-56.

3 Reber HA. Pancreatic duct and microvascular permeability to macromolecules: the relation to acute pancreatitis. Scand $\mathcal{F}$ Gastroenterol 1985; 20 (suppl 112): 96-100.

4 Wedgwood KR, Farmer RC, Reber HA. A model of haemorrhagic pancreatitis in cats - the role of 16,16-dimethyl prostaglandin $\mathrm{E}_{2}$. Gastroenterology 1986; 90: 32-9.

5 Karanjia ND, Lutrin FJ, Chang YB, Duong T, Reber HA Low dose dopamine protects against haemorrhagic pancreatitis in cats. F Surg Res 1990; 58: 440-3.

6 Karanjia ND, Widdison AL, Lutrin FJ, Chang YB, Reber HA. The anti inflammatory effect of dopamine in alcoholic haemorrhagic pancreatitis in cats. Studies on the receptors and mechanisms of action. Gastroenterology, 1991; 101: $1635-41$

7 Karanjia ND, Lutrin FJ, Chang YB, Duong T, Reber HA. The effect of alcohol, prostaglandin $\mathrm{E}_{2}$ and dopamine on pancreatic duct and or vascular permeability in cats. Pancreas 1989; 4: A622.

8 Hallenbeck GA. Biliary and pancreatic intraductal pressures. In: Heidl W ed. Handbook of physiology: Alimentary Canal: Vol II. Secretion. Baltimore: Waverly Press, 1967: 1007-25.

9 Gudgeon AM, Heath DI, Hurley PR, Jehanli A, Patel G, Wilson C, Shenkin A, Austen BM, Imrie CW, HermonTaylor J. Trypsinogen activation peptides assay in the prediction of severity of acute pancreatitis. Lancet 1990; 335: 4-8.

10 De Haen C, Neurath H, Teller DC. The phylogeny of trypsinrelated serine proteases and their zymogens. New methods rer the investigation of distant evolutionary relationships. for the investigation of distant

11 Vogel WC, Zieve L. A rapid and sensitive turbidimetric method for serum lipase estimation based upon differences between the lipase of normal and pancreatitis serum. Clin Chem 1963; 9: 168 .

12 Hurley PR, Cook A, Jehanli A, Austen BM, Hermon-Taylor J. Development of radioimmunoassays for free tetraL-aspartyl-L-lysine trypsinogen activation peptides (TAP) f Immuno Methods 1988; 111: 195-203.

13 Frey CF. Haemorrhagic pancreatitis. Am f Surg 1979; 137 616-23.

14 Kivilaakso E, Fraki O, Nikki P, Lempinen M. Resection of the pancreas for acute fulminant pancreatitis. Surg Gynecal Obst 1981; 152: 493-8.

15 Lokhandwala MF, Barrett RJ. Review cardiovascular dopamine receptors: physiological pharmacological and thera-

16 Dasta JF, Kirby MG. Pharmacology and therapeutic use of low dose dopamine. Pharmacotherapy 1986; 6: 304-10. 
17 Donohue PE, Akimoto H, Ferguson JL, Nyhus LM. Vasoactive drugs in acute pancreatitis. Arch Surg 1984; 119: 477-80.

18 Alvarez C, Widdison AL, Reber HA. The effect of low dose dopamine on the caerulein model of acute pancreatitis.

19 Glazer G, Bennett A, Dudley HAF. Elevation of prostaglandin like activity in the blood and peritoneal exudate of dogs with cute pancreatitis. Brf Surg 1974; 6: 922-5.

20 Hagen PO, Ofstad E, Amundson E. Experimental acute pancreatitis in dogs: histamine release induced by pancreatic exudate. Scand F Gastroenteral 1969; 4: 75-96.

21 Maino G, Shea SM, Leventhal M. Endothelial contraction induced by histamine type mediators: an electron microscopic study. $\mathcal{F}$ Cell Biol 1969; 42: 647-72.

22 Svensjo E, Adamski SW, Su K, Grega GJ. Quantitative physiological and morphological aspects of microvascular physiological and morphological aspects of microvascular terbutaline. Acta Physiol Scand 1982; 116: 265-73. 